GOULET, H. 2020: Nearctic Tenthredo: a monograph of the verticalis and prosopa groups (Hymenoptera: Tenthredinidae). - In: Nova Supplementa Entomologica, Müncheberg 26: $1-178$.

\title{
Corrections
}

Published on 2020-12-01

\section{Sources of lectotype designations}

A) For several new species described by MacGillivray, Norton and Cresson, and mentioned in my paper, the number of specimens was not stated in the original description. From the original descriptions, because the body length was given without a range, I suspected that only one specimen was involved. However, unknown to me, lectotypes for these had already been selected and published by Frison (1927) for MacGillivraY, by Cresson (1916) for Cresson, by Cresson (1928) for the Norton types in ANSP, and by RoHwER (1920) for a NorTon type in MCZC. The lectotype designations for the following species objectively remain the same as in my paper, i.e., they refer to the same specimens. However, the author of the designation is not Goulet (2020), but Frison (1927), Cresson (1916), Cresson (1928), or RoHwer (1920). The synonymic list should be modified as follows:

p. 75: Tenthredo bilineatus MacGillivray, 1895: 282. ("here designated" should be replaced by "designated by FrISON, 1927: 262"),

p. 112: Allantus mellinus NorTon, 1869: 248. ("here designated, MCZC" should be replaced by "designated by RoHwer, 1920: 518“). Norton had a male and a female, but did not mention which specimen was the holotype. RoHwer (1920: 518) listed the types, without specifying which of the two specimens would be the lectotype. He noted (p. 518) "Type and allotype in Harris collection under no. 516.", and on p. 509 "Mr. C. W. Johnson has kindly looked over the manuscript for this paper and under date of May 9, 1918, states he has marked the specimens here designated as types." The ICZN article 74.5. "Lectotype designation before 2000" does not require information to ensure the recognition of the specimen designated. Only after 1999 (the articles 74.7 and 74.7.2) is this a necessity. Furthermore, after "Allantus mellinus Harris. Manuscript name", "(nomen nudum)" should be replaced by "(undescribed)". Though Norton (1860: 248) mentioned that "A. mellinus" was a manuscript name by HARRIs, it was not published. This might have been only a specimen label with that name, written by T. W. Harris. This name does not appear in HARris (1835).

p. 124: Tenthredo bella Cresson 1880: 21. ("here designated" should be replaced by "designated by Cresson, 1916: 3"),

p. 140: Tenthredo rutata MacGillivray, 1923: 38. ("here designated" should be replaced by "designated by Frison, 1927: 266"), p. 144: Tenthredo secundus MacGillivray, 1897: 105. ("here designated" should be replaced by "designated by Frison, 1927: 266"),

p. 144: Tenthredo simulatus MacGillivray, 1897: 105. ("here designated" should be replaced by "designated by Frison, 1927: 267"),

p. 148: Tenthredo rubripes MacGillivray, 1900: 178. ("here designated" should be replaced by "designated by FrIsON, 1927: 266"),

p. 152: Tenthredo formosus NorTon, 1864: 14. ("here designated" should be replaced by "designated by Cresson, 1928: 6"),

p. 156: Tenthredo nova MacGillivray, 1897: 106. ("here designated" should be replaced by "designated by FrISON, 1927: 263"),

p. 156: Tenthredo causatus MacGillivray, 1900: 177. ("here designated" should be replaced by "designated by Frison, 1927: 262").

B) Tenthredo borealis described by KIRBy (1882) was based on two specimens [“a, b. ㅇ. (Types.)"]. I do not know who labeled a syntype as holotype. This specimen should be a lectotype and is selected on page 124 .

\section{Missing mentions of species distribution}

The type locality of Tenthredo carolina (ROHwER) and mentioned in the synonymic list (page 68) as being from Biltmore, NC $\left(35.567^{\circ}-82.542^{\circ}\right)$ was not given in the distribution or on the map. Similarly, T. bella CRESSON (under T.nordica) was described from Colorado [state record only] and mentioned in the synonymy (on page 124), but was not given in the distribution or on the map.

\section{Missing information about a type}

The type of Tenthredo relativus RoHwer, 1909: 108 (on page 136) was reviewed and listed by SмITH, 1983: 371. The reference should be under T. relativus before "Condition".

\section{Mislabeled plates}

p. 150: Figs 1.27 a-x. Change "Tenthredo vellosa" to "Tenthredo transversolinea"

p. 151: Figs 1.27 y-ae. Change "Tenthredo vellosa" to "Tenthredo transversolinea" 


\section{Acronym change}

In the list of collection acronyms, the collection "AEI" (on page 4), originally from Florida, has been moved to Utah State University, Logan, Utah.

\section{Wrong citation}

The citation "TAEgER et al. 2009" (on pages 108 and 111) refers to "Blank et al. 2009".

\section{Misplaced reference}

In the "References", Rohwer, S. A. 1909 (on page 177) should have been placed before RoHwer, S. A. 1913.

\section{Additional References for above changes}

Cresson, E. T. 1916: The Cresson Types of Hymenoptera. - Memoirs of the American Entomological Society, Philadelphia No. 1: 141 pp.

Cresson, E. T. 1928: The types of Hymenoptera in the Academy of Natural Sciences of Philadelphia other than those of Ezra T. Cresson. - Memoirs of the American Entomological Society, Philadelphia 5: $90 \mathrm{pp}$.
Frison, T. H. 1927: List of the insect types in the collections of the Illinois State Natural History Survey and the University of Illinois. - Bulletin of the Illinois State Laboratory of Natural History 16 (4): 137-309.

HARris, T. W. 1835: VIII. Insects. - In: Part IV. Catalogues of animals and plants. - In: Нітснсоск, E. 1835: Report on the geology, mineralogy, botany, and zoology of Massachusetts. Made and published by order of the government of that state: in four parts: Part I. Economical geology. Part II. Topographical geology. Part III. Scientific geology. Part IV. Catalogues of animals and plants. With a descriptive list of the specimens of rocks and minerals collected for the government. Illustrated by numerous wood cuts and an atlas of plates. Second edition, corrected and enlarged. - Amherst, Press of J. S. and C. Adams: XII + 1-700: 553-602.

Rohwer, S. A. 1920: Notes on the Harris collection of sawflies, and the species described by Harris. Journal of the Washington Academy of Sciences, Washington D. C. 10 (18): 508-518.

Smith, D. R. 1983: The Rohwer sawfly types (Hymenoptera: Symphyta) in the University of Nebraska State Museum. - Proceedings of the entomological Society of Washington 85 (2): 366-373. 